\title{
AZ ARMSTRONG WHITWORTH WHITLEY KÖZEPES BOMBÁZÓ REPÜLŐGÉP ALKALMAZÁSA SZÁLLÍTÓ REPÜLŐGÉPKÉNT A II. VILÁGHÁBORÚBAN
}

DOI: $10.30583 / 2018 / 1-2 / 303$

\section{Absztrakt}

Az 1937-ben szolgálatba állt, de 1940-re bombázó feladatkörben már elavult Armstrong Whitworth Whitley közepes bombázó repülögép alkalmazására elsősorban szállitó repülőgépként került sor a II. világháború során. A típussal ekkortól elsősorban utánpótlást, teherdeszantot és ejtőernyősöket szállitottak. 1941. február 10-én egy dél-olaszországi vízvezetékrendszer megsemmisítésére kapott feladatot egy brit SAS ejtőernyős kommandó. A csoportot Armstrong Whitworth Whitley bombázó repülögépek szállitották a hegyekben elhelyezkedő cél helyszínéhez. A fö csoportositással párhuzamosan, a vízvezetéktöl távolabb két másik, kisebb egységet is ledobtak. A vízvezetéket felrobbantották. Ezt követően a csoport $80 \mathrm{~km}$-es menetet hajtott volna végre a tengerpartig, ahol egy tengeralattjáró vette volna fedélzetére. Az erők kivonása azonban nem járt sikerrel.

Kulcsszavak: közepes bombázó repülögép, Armstrong Whitworth Whitley, brit haderő, Special Air Service, különleges múveletek, légideszant, ejtőernyőzés, légi szállítás, teherdeszant-ledobás

\section{Bevezetés}

Az 1937-ben szolgálatba állt, de 1940-re elavult Armstrong Whitworth Whitley közepes bombázó repülőgép alkalmazására elsősorban szállító repülőgépként került sor a II. világháború során. A típussal ekkortól elsősorban utánpótlást, teherdeszantot és ejtőernyősöket szállítottak. Az újonnan felállított brit ejtőernyős fegyvernemnek ugyanis égetően nagy szüksége volt légi szállító kapacitásra.

Dr. Klemensits Péter Pallas Athéné Geopolitikai Alapítvány, Dél- Délkelet-Ázsia Kutatóintézet, szenior kutató. Pallas Athéné Geopolitical Institute of SouthSoutheast Asia, Senior Researcher peterklemensits@yahoo.com ORCID: 00000003-2907-9130 


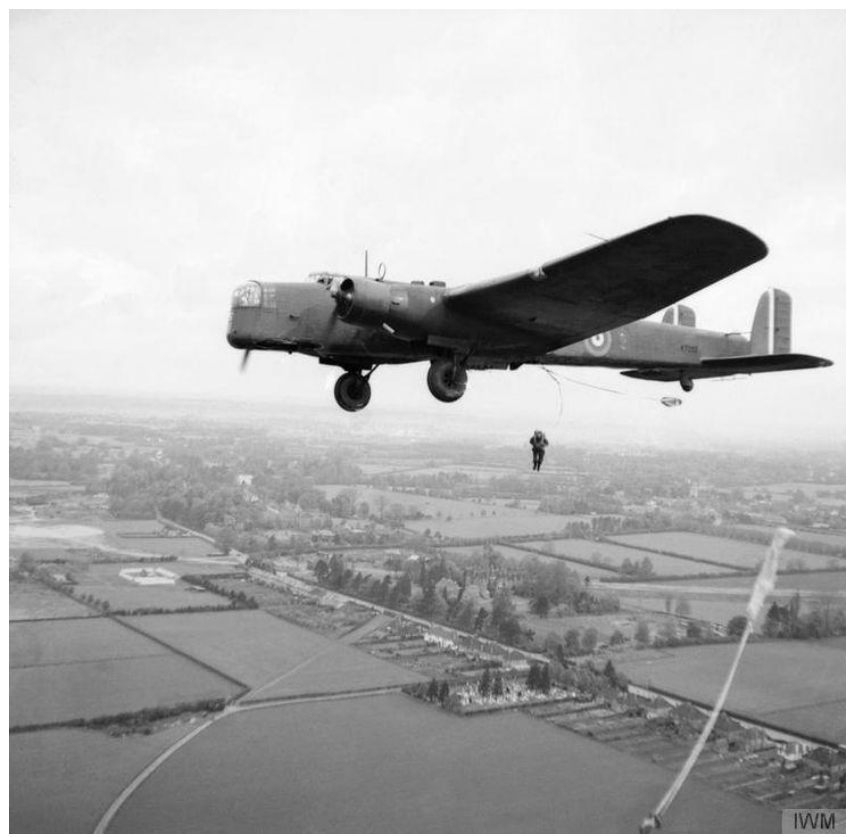

1. ábra. Ejtöernyős bekötött ugrása Whitley-böl egy gyakorlaton. Jól kivehetök a korábbi ugrók bekötökötelei a géptörzs alatt

A német ejtőernyős csapatok 1940-es nyugat-európai sikereit követően a britek is felismerték az új fegyvernem jelentőségét, ennek következtében Winston Churchill miniszterelnök nyomására már 1940 júniusában döntés született a légideszant alakulatok szervezéséröl.[2] Elöször 500 önkéntes felkészítése kezdődött meg Manchester közelében, melyek első bevetését 1941 tavaszára tervezték, de a kiképzést számos tényező hátráltatta.

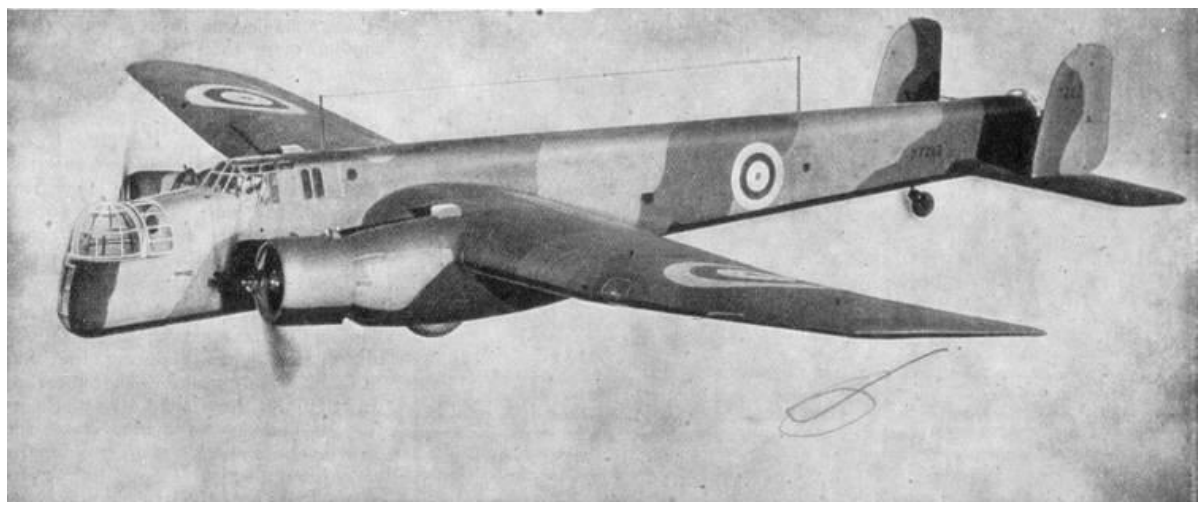

2. ábra. A brit Armstrong Whitworth Whitley közepes bombázó repülögép.

Az elavult repülőgépet ejtőernyősök ledobására is alkalmazták. 
A britek nem rendelkeztek katonai célokra felhasználható vitorlázó repülőgépekkel, és a szállító repülőgépek elenyésző száma is problémát jelentett. A megfelelő szervezeti keretek kialakítása sem bizonyult egyszerü feladatnak, a hadsereg és a légierő közötti rivalizálás pedig további késedelmet eredményezett. Végül elfogadták David Stirling százados koncepcióját egy ejtőernyős különleges hadviselési erő felállításáról, így létrejött az SAS (Special Air Service - Különleges Légi Szolgálat).[1] Az ejtőernyősök szállítására, később a vitorlázó repülőgépek vontatására speciálisan átalakított Armstrong Whitworth Whitley közepes bombázókat alkalmaztak. Ezek ekkorra bombázóként már elavultak, de ejtőernyős-szállító feladatkörben még több évig megfelelőnek bizonyultak.

\section{A brit Armstrong Whitworth Whitley közepes bombá- zó repülögép}

1937-ben bombázó repülőgépként rendszerbe állt a vállszárnyas, kétmotoros, osztott vezérsíkkal rendelkező Armstrong Whitworth Whitley közepes bombázó repülőgép.

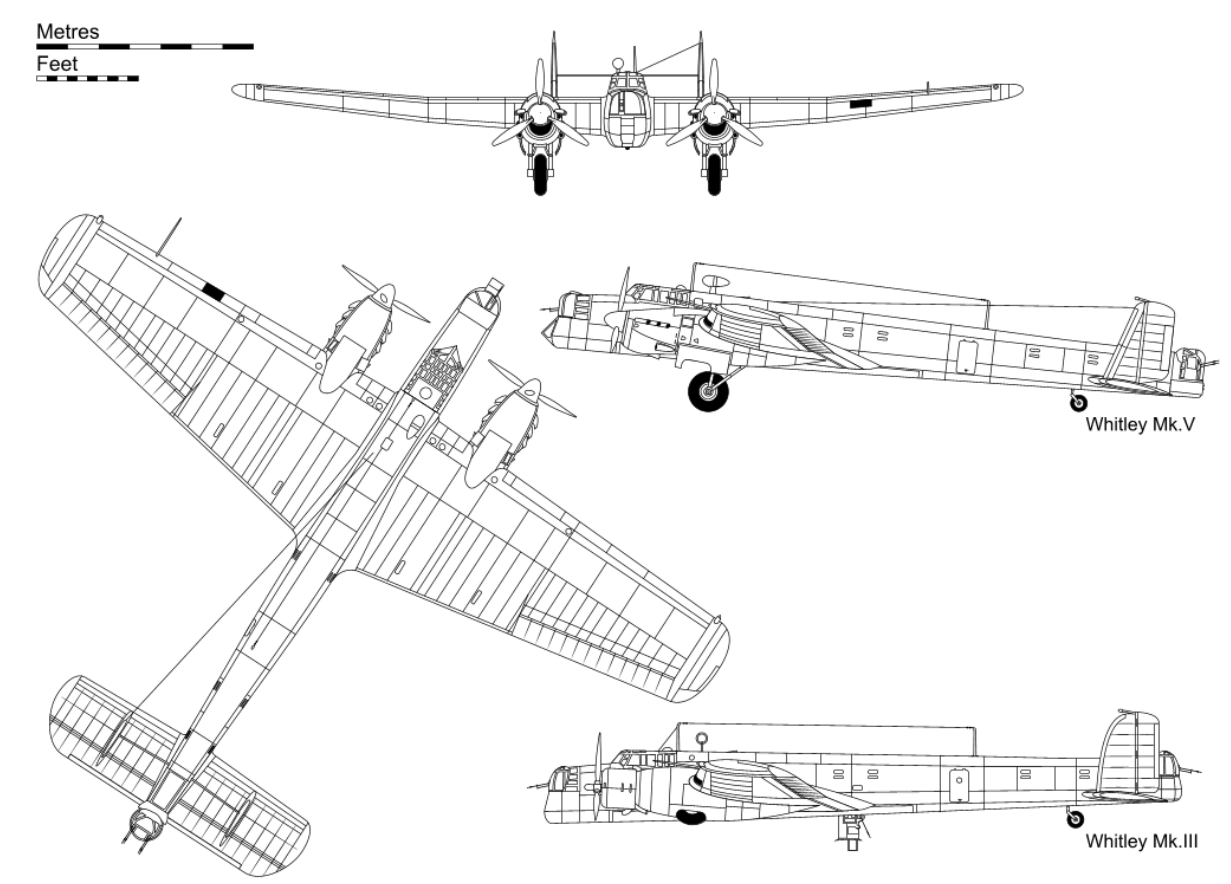

3. ábra. A brit Armstrong Whitworth Whitley közepes bombázó repülögép háromnézeti rajza 
Whitley Mk.I-es változatának (34 db) és a továbbfejlesztett, sorozatban gyártott Mk.II-esnek (126 db), illetve az Mk.III-asnak (80 db) Armstrong Siddeley Tiger típusú léghütéses csillagmotorja volt. Az Mk.IV-es sorozatba (33 db) már folyadékhütéses 1145 LE-s RollsRoyce Merlin X típusú 12 hengeres V-motorok kerültek.

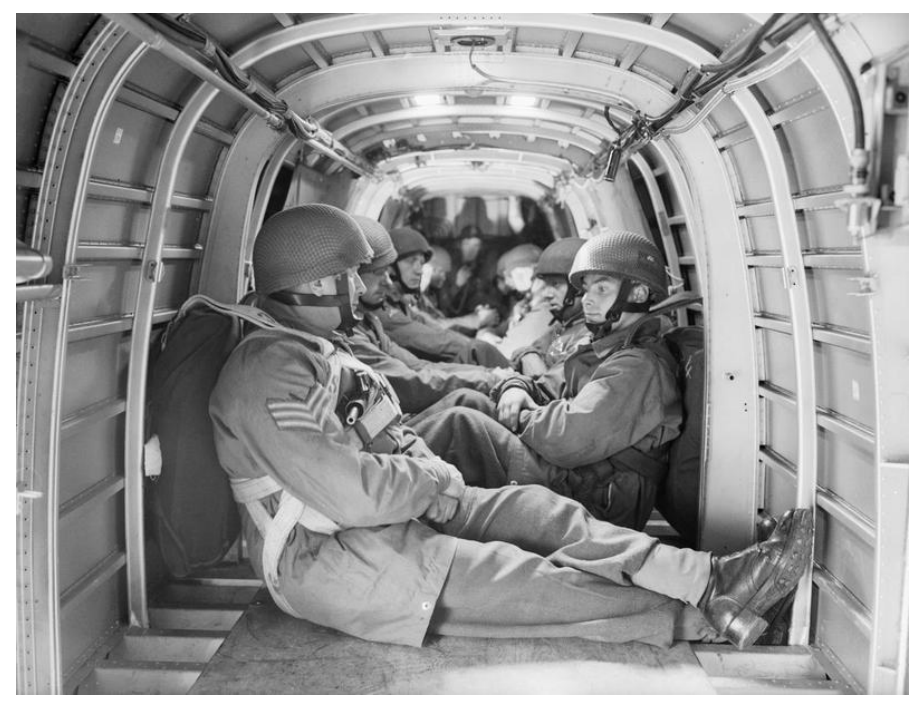

4. ábra. Ejtőernyősök a Whitley bombázó törzsében

AZ ARMSTRONG WHITWORTH WHITLEY FÖBB ADATAI [4]

\begin{tabular}{|l|c|}
\hline Fesztávolság & $26 \mathrm{~m}$ \\
\hline Törzshossz & $21 \mathrm{~m}$ \\
\hline Eröforrás & $\begin{array}{c}2 \times 920 \text { LE Armstrong } \\
\text { Siddeley Tiger csillagmotor }\end{array}$ \\
\hline Szerkezeti tömeg & $8800 \mathrm{~kg}$ \\
\hline Hasznos teher & $6400 \mathrm{~kg}$ \\
\hline Fegyverzet & $\begin{array}{c}1 \times 0,303 \text { hüvelyk }(7,7 \mathrm{~mm}) \text { forg. gpu. orrtoronyban, } \\
4 \times 0,303 \text { hüvelyk }(7,7 \mathrm{~mm}) \text { forg. gpu faroktoronyban, } \\
3177 \mathrm{~kg} \text { bomba }\end{array}$ \\
\hline Sebesség & $370 \mathrm{~km} / \mathrm{h}$ \\
\hline Hatótáv & $2650 \mathrm{~km}$ \\
\hline Csúcsmagasság & $7915 \mathrm{~m}$ \\
\hline Szolgálati idö & $1937-1942$ \\
\hline Legyártva & $1814 \mathrm{db}$ \\
\hline
\end{tabular}


A legfontosabb változat, az Mk.V. (1466 db) hátul meghosszabbított törzzsel, módosított farokrésszel és nagyobb üzemanyagtartállyal készült. $\mathrm{A}$ típus a háború első éveiben már csak a Partvédelmi $\mathrm{Pa}$ rancsnokság számára látott el járőr- és tengeralattjáró-elhárítási feladatokat. Az Mk.VII-es szériát (146 db) ezért levegő-vízfelszín felderítési feladatok ellátására alkalmas radarral szerelték fel a Partvédelmi Parancsnokság részére.

A brit haderő az elavult és lassú Whitley közepes bombázó repülőgépet 1941-ben ejtőernyősök ledobására is alkalmazta. Az ejtőernyősök - maximum 10-12 fö - a Whitley szükös törzsében utaztak a célig, majd a bombázógép padlólemezén kialakított kerek nyíláson keresztül hajtották végre az ejtőernyős ugrást.
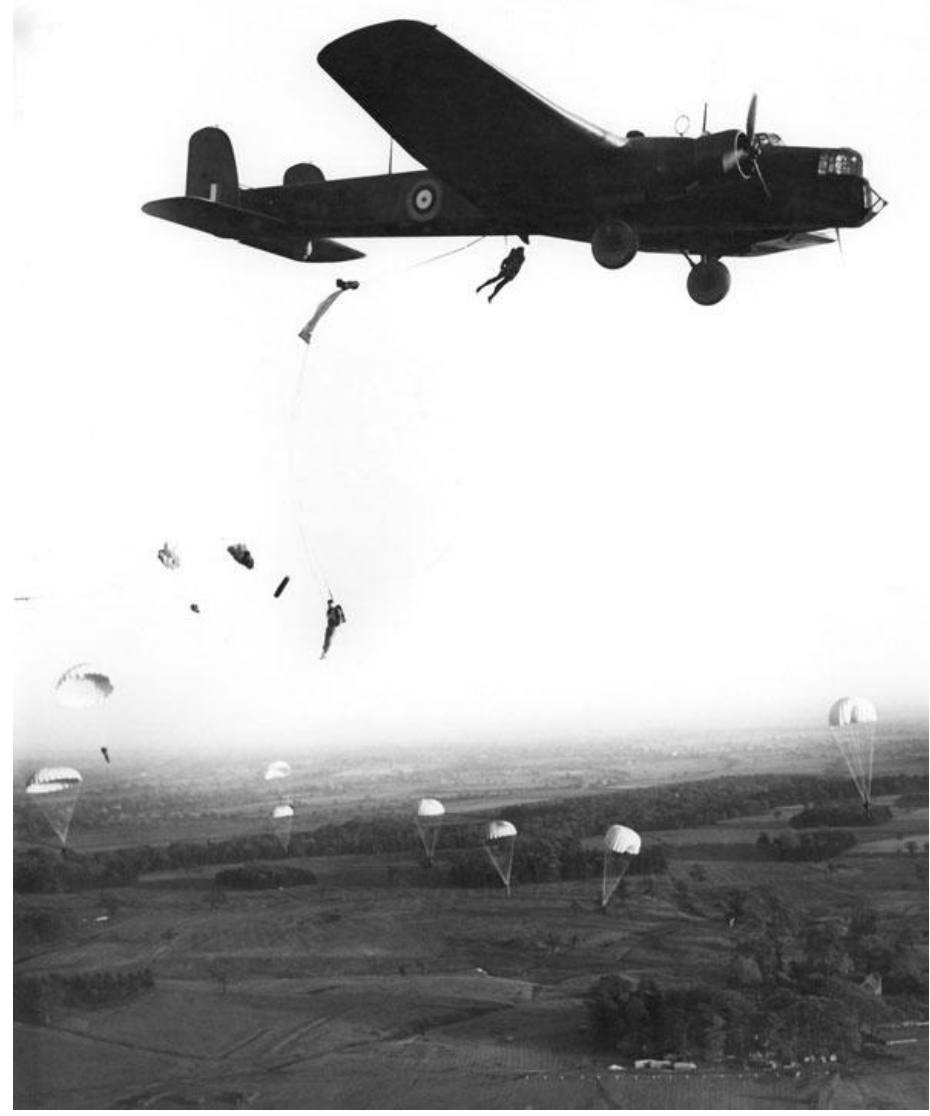

5. ábra. Az Armstrong Whitworth Whitley bombázógépek padlólemezén kialakított kerek nyíláson keresztül hajtottak végre ugrást a brit ejtőernyősök 
A Whitley bombázó padlólemezén kialakított deszantnyílás csak vontatottan tette lehetővé az ejtőernyősök kijuttatását, amely fokozta az erők szétszóródását. Rendszerint bekötött ugrásokat hajtottak végre a Whitley-böl.

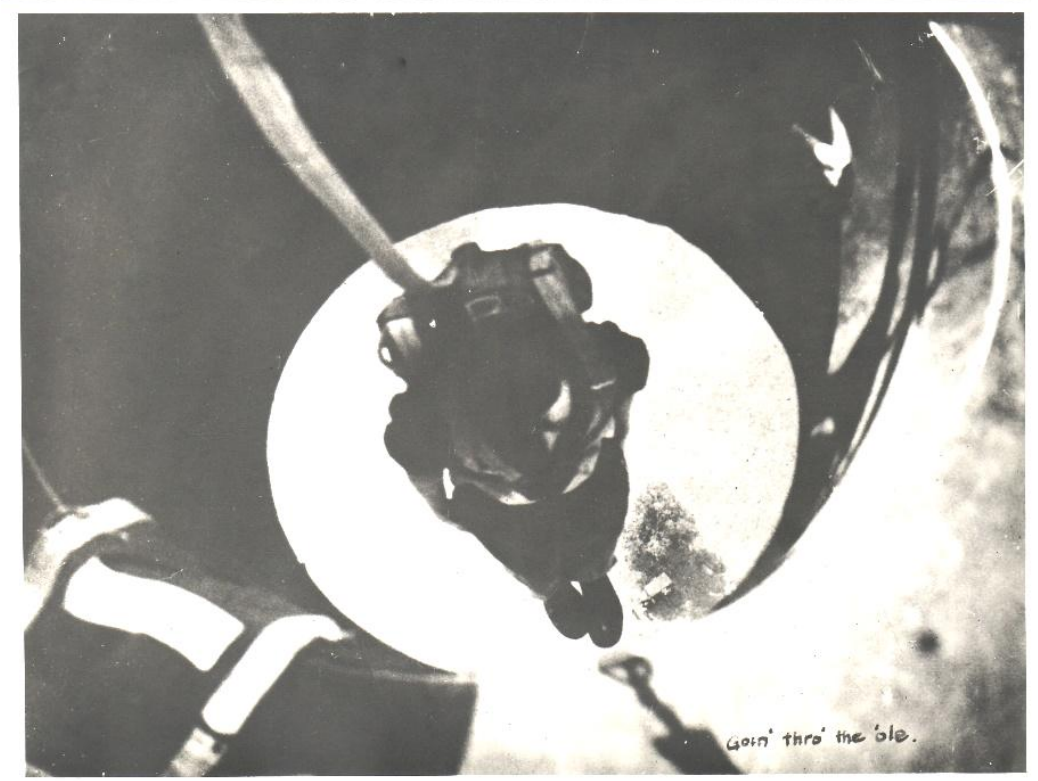

6. ábra. A Whitley bombázó padlólemezén kialakított deszantnyílás

E célra rögzítési pontot alakítottak ki a bekötőkötelek számára a géptörzsben. A repülőgép - az ejtőernyősök támogatására - felszerelést és ellátmányt tartalmazó teherdeszant-konténert dobhatott le bombakamrájából.

\section{A Különleges Légi Szolgálat és a katonai ejtőernyö- zés}

Az ejtőernyős csapatok magvát a 2-es számú kommandó jelentette, melynek 342 katonája sikeresen teljesítette a kiképzést, ezután 1940 végén, mint a 11. speciális légi szolgálati zászlóalj (Special Air Service - Különleges Légi Szolgálat - SAS) kapott bevetésre alkalmas minősítést.

1941-ben létrejött az első SAS század.1941-ben létrejött az első szállítórepülő-ezred is az ejtőernyősök müveleteinek támogatására, illetve vontatási és szállítási feladatok végrehajtására.[5] A technikai 
és szervezeti hiányosságok ellenére (vitorlázó repülőgépek továbbra sem álltak rendelkezésre) az ejtőernyősök éles bevetése nem tűrt halasztást, hiszen a tapasztalatokra égető szüksége volt a királyi légierőnek, emellett politikai okokból kifolyólag a fegyveres erők ütőképességét is bizonyítani kellett. Ekkor jutott szerephez a bombázó repülőgépként már elavult, de szállító repülőgépként még használható Armstrong Whitworth Whitley, mivel az újonnan felállított brit ejtőernyős fegyvernemnek szüksége volt a típus légi szállító kapacitására.

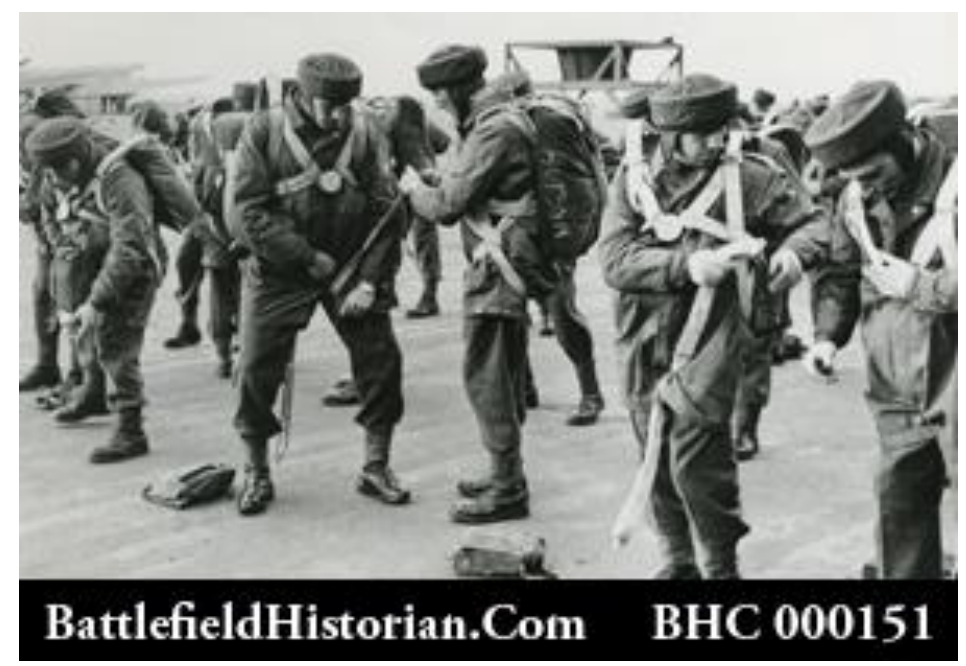

7. ábra. Ejtőernyős kiképzésen a Colossus müveletben részt vevő 11. SAS zászlóalj katonái

\section{A Colossus hadmúvelet és a Whitley bombázó}

A britek számára 1940-41 telén Észak-Afrika jelentette az egyetlen aktív hadszínteret, ahol Olaszország ellen folytak a hadmúveletek, a célpont kiválasztásánál az olasz háborús erőfeszítések akadályozása volt a meghatározó elv. Ennek következtében Calitri mellett a Tragino folyón átívelő vízvezetékre esett a választás, amely a tarantói haditengerészeti bázis mellett közel 2 milliós lakosságot látott el ivóvízzel. Az objektum megsemmisítésével a brit hadvezetés komoly csapást akart mérni az ellenség moráljára, ezt pedig kizárólag az ejtőernyősök bevetésével tartotta kivitelezhetőnek.

Az ejtőernyős zászlóalj kötelékéből T. A. G. Pritchard őrnagy vezetésével 38 embert választottak ki a Colossus hadmüveletre (hozzájuk csatlakozott még 3 olasz tolmács), az egység pedig az $X$ szakasz 
megjelölést kapta. Hathetes kiképzést követően az alakulat 1941. február 10-re már készen állt a feladatra. A terv szerint figyelemelterelő bombázásokkal egyidejüleg a deszantosok földet érésük után robbantással megsemmisítik a vízvezetéket, majd a Sele folyó torkolatánál gyülekeznek, ahol a Triumph tengeralattjáró fogja várni őket.

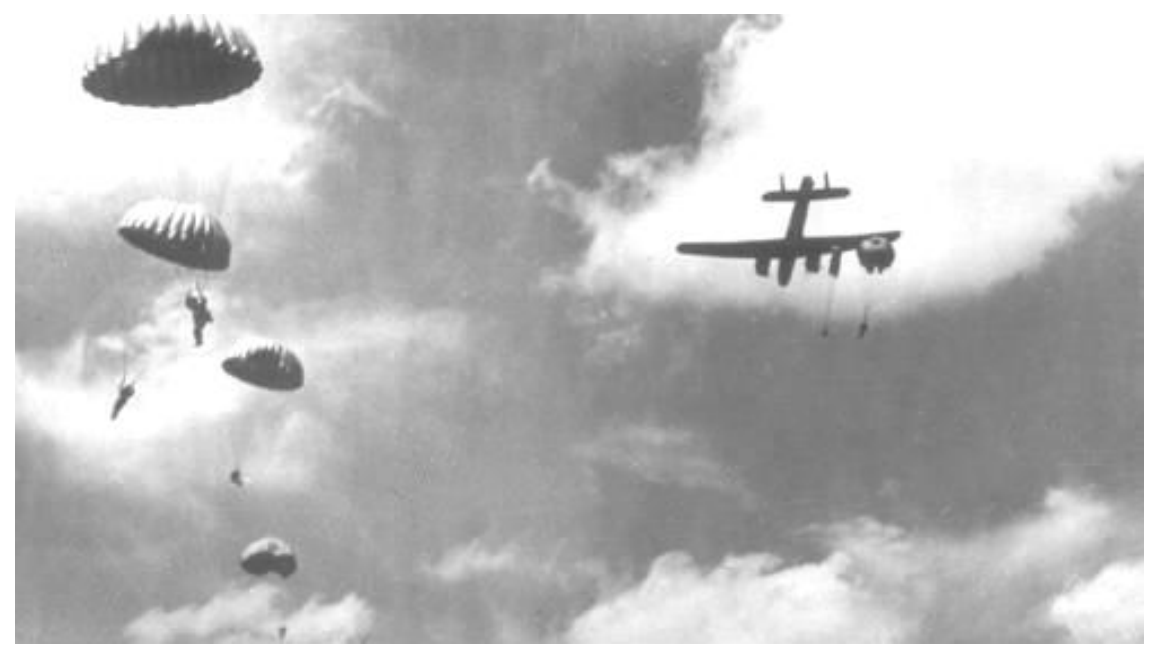

8. ábra. A Colossus müveletnél alkalmazott Armstrong Whitworth Whitley bombázó repülögépek ejtőernyősöket dobnak le

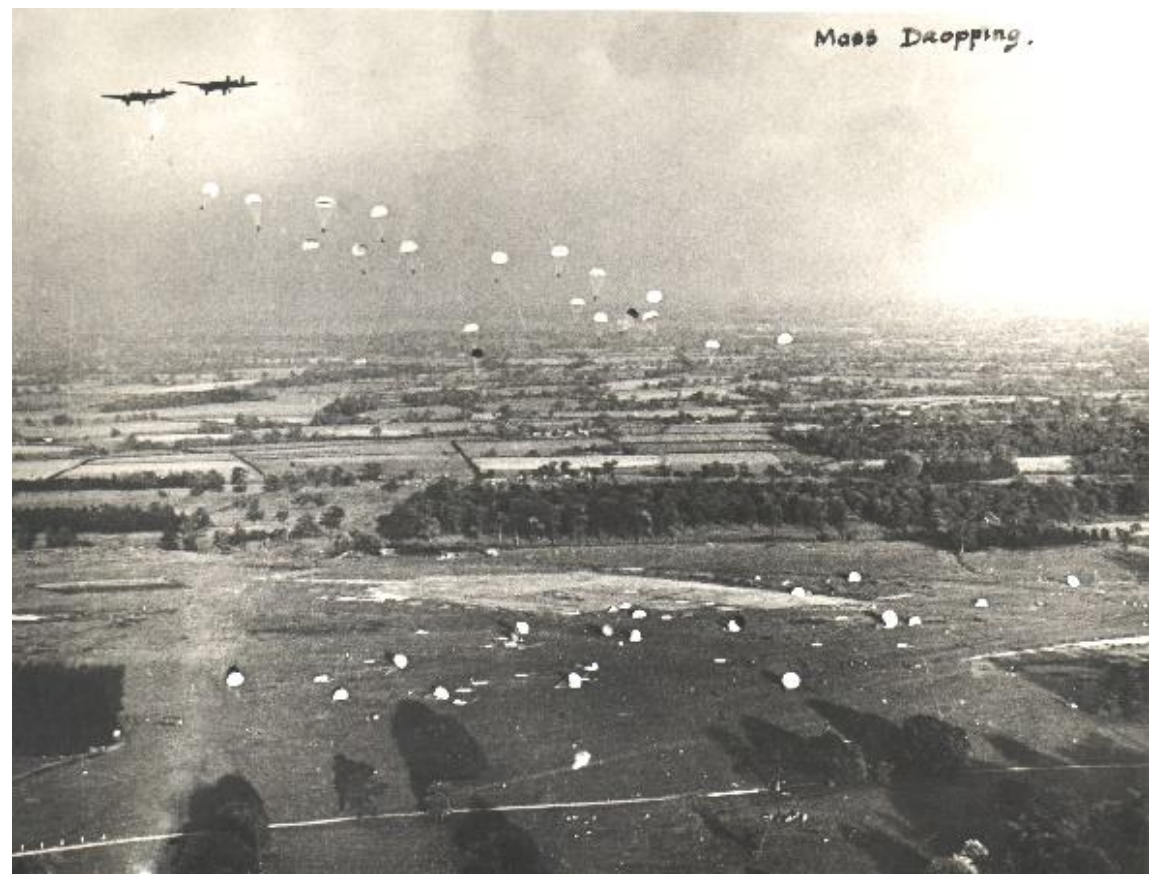

9. ábra. Tömeges ejtőernyős ledobás Whitley-ből 
Február 10-én a $6 \mathrm{db}$ Whitley bombázó a tervek szerint elindult Máltáról, de 2 gép a fagyás okozta meghibásodás miatt képtelen volt ledobni terhét, az utolsó pedig a célkörzetet sem találta meg, így a fedélzetén utazó ejtőernyősök a tervezettnél később és távolabb értek földet. Ráadásul - műszaki katonákról lévén szó - a felszerelés nagy része is náluk volt. Szerencséjükre Pritchard emberei saját konténereiket megtalálták, így elegendő robbanóanyaggal rendelkeztek a küldetés teljesítéséhez, és a vízvezeték mellett egy hidat is felrobbantottak.

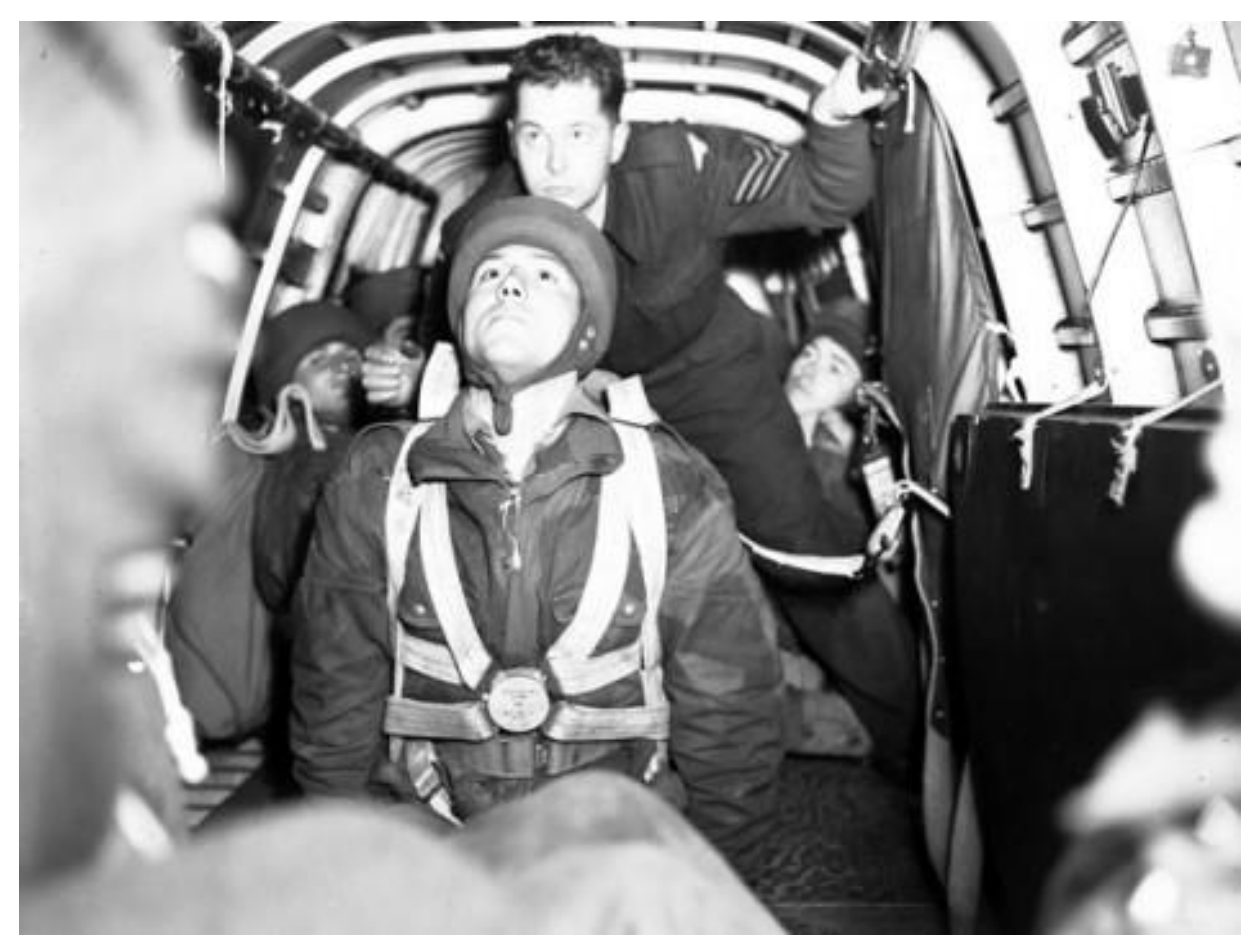

10. ábra. Ugrás előtti pillanat, az ejtőernyős már félig az Armstrong Whitworth Whitley repülőgép padlólemezén kialakitott nyílásban van.

Sem a szükös törzs, sem a ledobónyílás nem volt ergonomikus kialakítású

Miután az ejtőernyősök egy, a földet éréskor megsebesült társukat hátrahagyták, 3 csoportban azonnal a tengerpart felé indultak, de rövidesen hadifogságba estek. Pritchard csoportját észrevette egy helyi parasztgazda, aki értesítette a csendőrséget, ezért a britek jelentős túlerővel néztek szembe. A másik két csoporton is olasz katonák és csendőrök ütöttek rajta, a felesleges áldozatokat elkerülendő végül Pritchard a megadást választotta. Az olasz hatóságok a briteket a sulmonai hadifogolytáborba szállították, az egyik olasz tolmácsot vi- 
szont kivégezték.

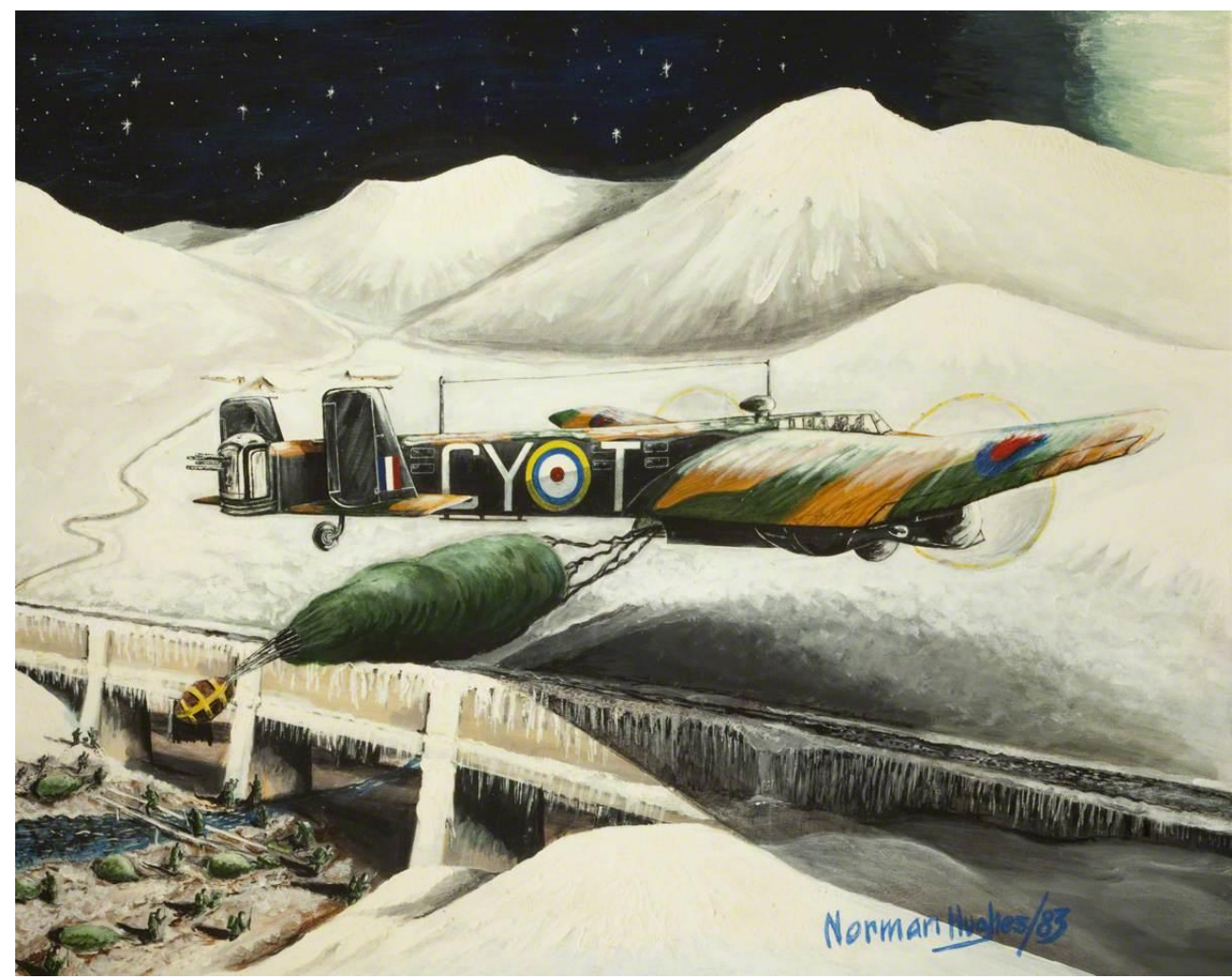

11. ábra. Armstrong Whitworth Whitley közepes bombázó repülögép teherdeszant-konténert dob le az ejtöernyősök támogatására bombakamrájából a Colossus müvelet során (grafika)

Az ejtőernyősök csupán az olasz fegyverletételt követően szabadultak, Anthony Deane-Drummond hadnagy kivételével, aki még korábban megszökött és sikeresen hazatért Angliába. (A hadnagy elöször 1941 decemberében próbálkozott a szökéssel, de a svájci határ közelében elfogták, végül 1942 májusában sikerült meglépnie egy firenzei kórházból és eljutnia Svájcba, ahonnan Dél-Franciaországon keresztül júliusban tért vissza hazájába.) Korántsem mellékes, hogy ha a szakasz tagjai sikeresen elérték volna a tengerpartot, akkor sem várta volna őket a tengeralattjáró, amelyet a hadvezetés Pritchardék tudta nélkül visszarendelt. Mivel a Sele torkolatánál a találkozóhely közelében egy brit bombázó a vízbe zuhant, a föparancsnokság számítva arra, hogy az olaszok lehallgatták a pilóta rádióüzenetét (és feltételezhetően a gép keresésére indulnak), túl kockázatosnak minősítette a tengeralattjárós akciót, tartva az ellenség csapdájától. 


\section{Összegzés}

A hadművelet eredményesége abban a tekintetben megkérdőjelezhető, hogy a feladat sikeres teljesítése ellenére a vízvezetéket az olaszok rövid időn belül helyreállították, így a háborús erőfeszítéseiket nem gátolta, habár a hasonló esetektől való félelem aláásta az olasz lakosság nyugalmát és új rendszabályok bevezetését tette szükségessé. Az ejtőernyős szakasz elvesztése részben a főparancsnokság hibás tervezésének tudható be, hiszen a katonák hazaszállítását nem sikerült biztosítani.

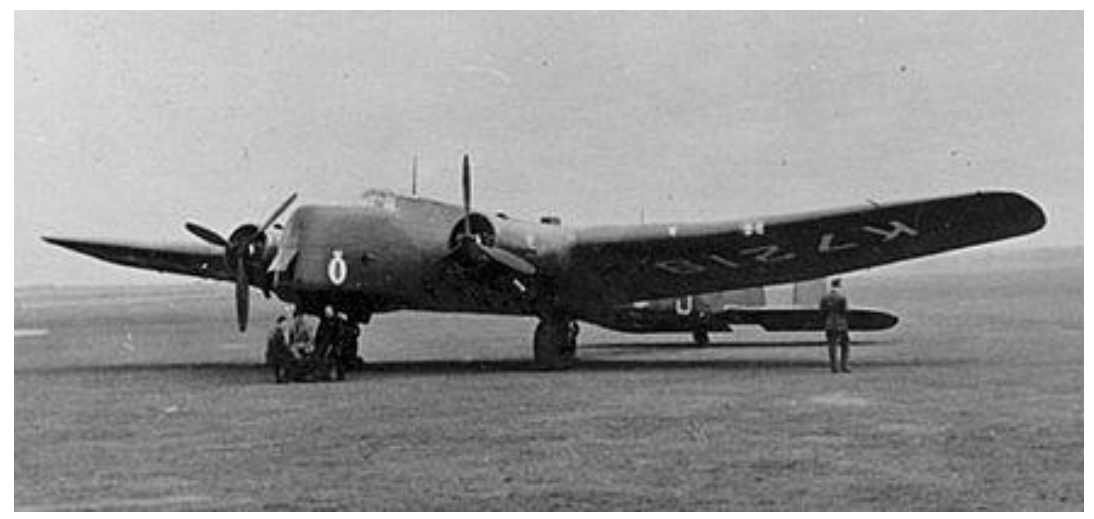

12. ábra. Whitley III repülögép a földön

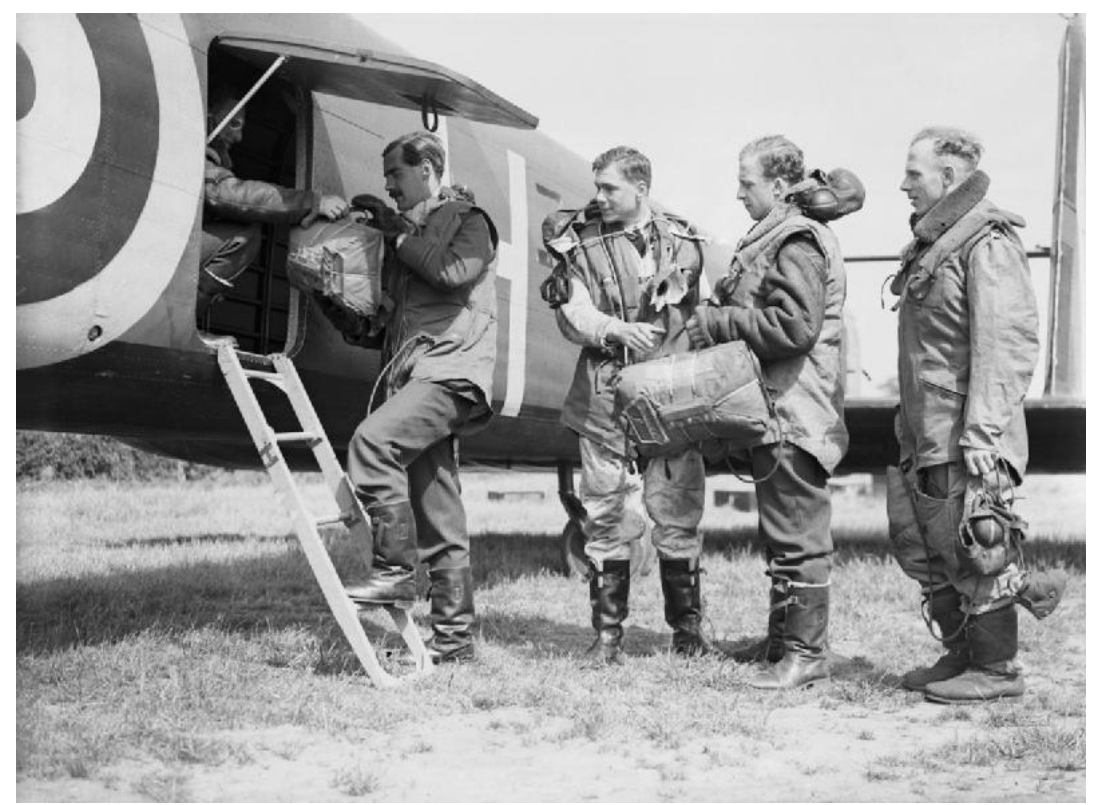

13. ábra. Ejtőernyősök beszállása Whitley bombázó repülőgépbe 
Mindazonáltal (a veszteségek ellenére) a Colossus hadművelet rávilágított az ejtőernyős fegyvernem jelentőségére, emelte az érintett brit csapatok morálját, és hosszú távon számos alapvető tapasztalattal gazdagította a hadvezetést a légideszant alakulatok jövőbeni alkalmazását tekintve.

Az, hogy az Armstrong Whitworth Whitley közepes bombázó repülőgép-típussal 1940-től elsősorban utánpótlást, teherdeszantot és ejtőernyősöket szállítottak, lényegében használható megoldásnak bizonyult a Colossus müvelet során, hiszen a brit ejtőernyős fegyvernemnek nagy szüksége volt légi szállító kapacitásra. A további háborús évek ejtőernyős müveletei bizonyították a brit légideszantok létjogosultságát.[3] Ekkorra azonban - 1942 után - a Whitley bombázó repülőgépet inkább mint deszantvitorlázó-vontatót, illetve ejtőernyős kiképző repülőgépet alkalmazták.

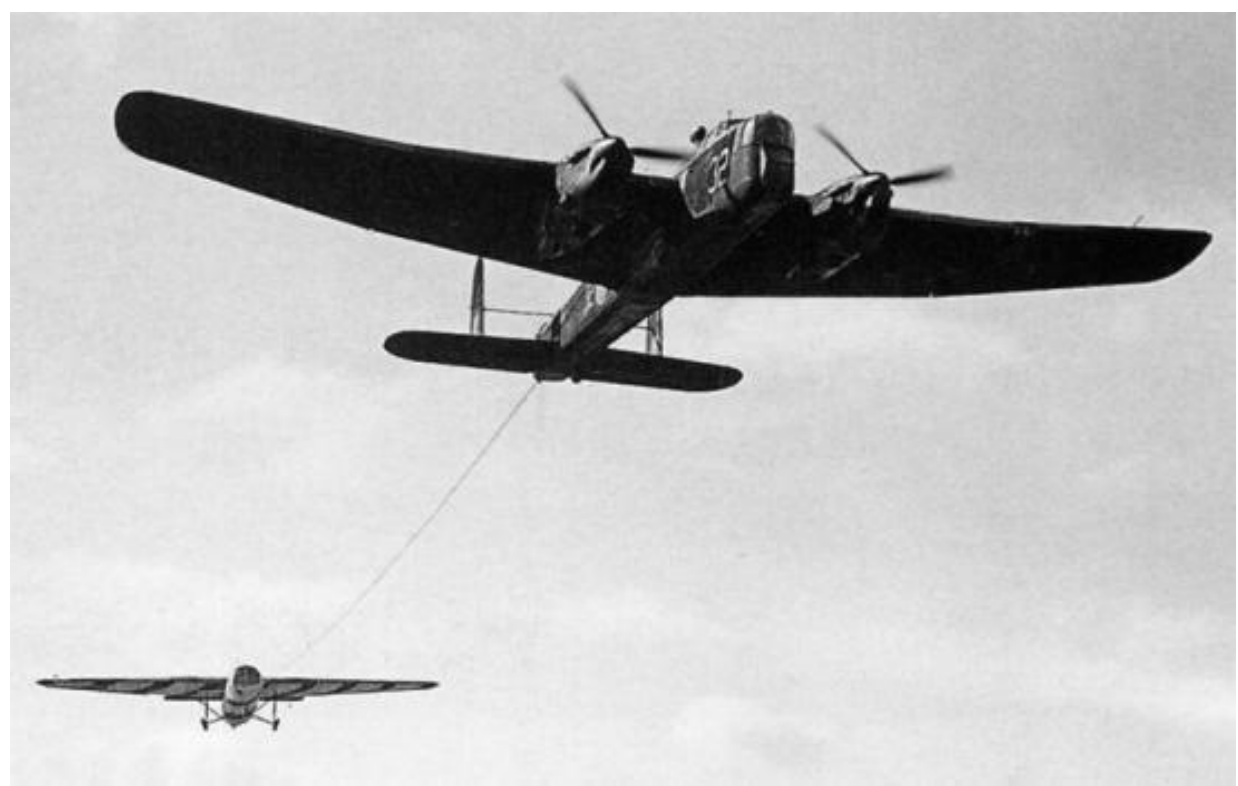

14. ábra. Whitley bombázó repülőgép, mint deszantvitorlázó-vontató

Az Armstrong Whitworth Whitley közepes bombázó repülőgép, mint elavult haditechnikai eszköz további, más feladatkörben történő hasznosítása mutatja azt, hogy még egy olyan jelentős anyagi erőforrások felett diszponáló nagyhatalom, mint a Brit Birodalom esetében is fontos volt a háború során az észszerü gazdálkodás a haditechnikai eszközökkel. 


\section{Források}

[1] A SAS Enciklopédia Zagora Kft. Budapest, 2000.

[2] Barry Gregory: The British Airborn Troops 1940-1945. Garden City, Doubleday, 1974.

[3] Turcsányi Károly - Hegedűs Ernő: A légideszant 1. köt. Elméletek, eljárások és a légi gépesítés a kezdetektől 1945-ig. Debrecen: Puedlo Kiadó, 2007.

[4] Green, William - Gordon Swanborough: Armstrong Whitworth's Willing Whitley. Air Enthusiast. 1979. évi 9. sz. 10-25. o.

[5] Richard Townshend Bickers: Military Air Transport - The Illustrated History. Osprey, London, 1998. 